пути повышения качества творога // Молочная промышленность. - 2006. - № 7. - С. 47.

5. Состав и свойства молока как сырья для молочной промышленности / Н.Ю. Алексеева [и др.]; под ред. Н.Ю. Костина. - М.: Агропромиздат, 1986. - 239 с.

Галстян Бардух Сарибекович, канд. техн. наук, старший преподаватель, Шушинский технологический университет. Республика Армения.

Республика Армения, г. Шуши, ул. Ашота Бекора, 4.

Тел.: +374 47731022 .

Ключевые слова: зернистый творог; сыр; сывороточный белок; бактерии; сычужный фермент.

\title{
THE STUDY OF GRANULAR COTTAGE CHEESE IN THE PROCESS OF FERMENTATION
}

Galstyan Bardukh Saribekovich, Candidate of Technical Sciences, Senior Teacher, Shusha Technological University. Republic of Armenia.

Keywords: granular cottage cheese; cheese; whey protein; bacteria; rennet ferment.
The article is devoted to the use in food purposes of whey and its constituent particles, in particular protein, in order to improve the yield of milk protein, enhance its functional properties, increase the role of protein in human nutrition.

\section{удк 631.354.2 \\ РЕЗУЛЬТАТЫ ИССЛЕДОВАНИЙ ДЛИНЫ И ДИАМЕТРА МОЛОТИЛЬНОГО БАРАБАНА ЗЕРНОУБОРОЧНЫХ КОМБАЙНОВ}

\author{
ДЕМИН Евгений Евгеньевич, Саратовский государственный аграрный университет имени \\ Н.И. Вавилова
}

СТАРЦЕВ Александр Сергеевич, Саратовский государственный аграрный университет имени Н.И. Вавилова

АНАНЬЕВ Вячеслав Андреевич, Саратовский государственный аграрный университет имени Н.И. Вавилова

МАВЗОВИН Владимир Святославович, Саратовский государственный аграрный университет имени Н.И. Вавилова

В результате исследований величин технических характеристик зерноуборочных комбайнов отечественных и зарубежных моделей и модификаций проанализированы значения длины и диаметра молотильного барабана комбайнов. Получены теоретические и эмпирические законы рядов распределений, математическое ожидание, среднеквадратичное отклонение, коэффициент вариации, доверительный интервал среднего значения, 95\%-й размах распределения длины и диаметра молотильного барабана зерноуборочных комбайнов и коэффициента длины молотильного барабана по диаметру.

Введение. Повышение технического и технологического уровня зерноуборочных комбайнов одно из основных направлений их развития [5]. При исследовании технических характеристик комбайнов (номинальной мощности установленного двигателя, массы без жатки, площади решет и соломотряса, длины молотильного барабана, объема бункера) установлены зависимости между их основными показателями $[1,2,9,10]$.

Цель исследования - совершенствование технических средств и технологических процессов зерноуборочных комбайнов.

Методика исследований. Особое значение в технологическом процессе зерноуборочного комбайна имеют длина и диаметр молотильного барабана $[3,6,7,11]$. Нами были поставлены задачи исследовать значение длины и диаметра молотильного барабана комбайнов и получить законы их распределения; определить отношение длины барабана к его диаметру для различ- ных моделей и модификаций зерноуборочных комбайнов отечественных и зарубежных производителей.

При этом мы ввели новое техническое понятие - коэффициент длины молотильного барабана по диаметру:

$$
\psi_{L D}=L_{\sigma} / D_{\text {б }},
$$

где $L_{6}$ - длина молотильного барабана, мм; $D_{6}-$ диаметр молотильного барабана, мм.

Для решения задач собраны технические характеристики зерноуборочных комбайнов ведущих мировых производителей сельскохозяйственной техники и определены численные значения коэффициента $\psi_{L D}$ (табл. 1$)$. 
Модели комбайнов со значениями коэффициента длины молотильного барабана по диаметру $\psi_{L} / D$

\begin{tabular}{|c|c|c|c|c|c|c|c|c|c|c|c|}
\hline $\begin{array}{c}\text { № } \\
\text { П/ா }\end{array}$ & Модель комбайна & $\psi_{L / D}$ & $\begin{array}{c}\text { № } \\
\text { П/ா }\end{array}$ & $\begin{array}{c}\text { Модель } \\
\text { комбайна }\end{array}$ & $\psi_{L / D}$ & $\begin{array}{l}\text { № } \\
\text { П/ா/ }\end{array}$ & $\begin{array}{c}\text { Модель } \\
\text { комбайна }\end{array}$ & $\psi_{L / L}$ & 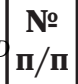 & $\begin{array}{c}\text { Модель } \\
\text { комбайна }\end{array}$ & $\psi_{L / D}$ \\
\hline 1 & 2 & 3 & 4 & 5 & 6 & 7 & 8 & 9 & 10 & 11 & 12 \\
\hline 1 & VECTOR 410 & 1,5 & 2 & VECTOR 420 & 1,5 & 3 & ДОН 1200 & 1,5 & 4 & ДОН 1200Б & 1,5 \\
\hline 5 & КЗС 3 & 1,5 & 6 & КЗС-8 & 1,5 & 7 & $\begin{array}{l}\text { SAMPO } \\
\text { SR2010 }\end{array}$ & 1,56 & 8 & ЕНИСЕЙ 960 & 1,67 \\
\hline 9 & New Holland TC5040 & 1,71 & 10 & $\begin{array}{l}\text { New Holland } \\
\text { TC5050 }\end{array}$ & 1,71 & 11 & $\begin{array}{c}\text { New Holland } \\
\text { TC54M }\end{array}$ & 1,72 & 12 & $\begin{array}{c}\text { New Holland } \\
\text { TC54H } \\
\end{array}$ & 1,72 \\
\hline 13 & New Holland CX 8030 & 1,73 & 14 & $\begin{array}{l}\text { New Holland } \\
\text { CX } 8040\end{array}$ & 1,73 & 15 & $\begin{array}{c}\text { New Holland } \\
\text { CX8050 }\end{array}$ & 1,73 & 16 & $\begin{array}{c}\text { New Holland } \\
\text { CX 720 } \\
\end{array}$ & 1,73 \\
\hline 17 & $\begin{array}{l}\text { New Holland } \\
\text { CX740 }\end{array}$ & 1,73 & 18 & $\begin{array}{c}\text { New Holland } \\
\text { CX760 }\end{array}$ & 1,73 & 19 & $\begin{array}{c}\text { New Holland } \\
\text { CX780 }\end{array}$ & 1,73 & 20 & $\begin{array}{l}\text { Laverda } \\
184 \mathrm{AL} \\
\end{array}$ & 1,8 \\
\hline 21 & ACROS 530 & 1,87 & 22 & ACROS 540 & 1,87 & 23 & ACROS 560 & 1,87 & 24 & ДОН 161 & 1,87 \\
\hline 25 & ДОН 1500 & 1,87 & 26 & ДОН 1500Б & 1,87 & 27 & ДОН 1500М & 1,87 & 28 & КЗС-10 & 1,87 \\
\hline 29 & дОН 091 & 2 & 30 & CK -5 & 2 & 31 & CK $-5 \mathrm{M}$ & 2,0 & 32 & $\begin{array}{l}\text { ЕНИСЕИ } \\
\text { КЗС } 970\end{array}$ & 2,08 \\
\hline 33 & New Holland CX 8060 & 2,08 & 34 & $\begin{array}{l}\text { New Holland } \\
\text { CX } 8070\end{array}$ & 2,08 & 35 & $\begin{array}{c}\text { New Holland } \\
\text { CX } 8080\end{array}$ & 2,08 & 36 & $\begin{array}{l}\text { New Holland } \\
\text { CX8090 }\end{array}$ & 2,08 \\
\hline 37 & $\begin{array}{l}\text { New Holland } \\
\text { CX820 }\end{array}$ & 2,08 & 38 & $\begin{array}{c}\text { New Holland } \\
\text { CX840 }\end{array}$ & 2,08 & 39 & $\begin{array}{c}\text { New Holland } \\
\text { CX860 }\end{array}$ & 2,08 & 40 & $\begin{array}{c}\text { New Holland } \\
\text { CX880 } \\
\end{array}$ & 2,08 \\
\hline 41 & John Deere W540 & 2,12 & 42 & \begin{tabular}{|c|} 
John Deere T \\
550
\end{tabular} & 2,12 & 43 & \begin{tabular}{|c|} 
John Deere T \\
560
\end{tabular} & 2,12 & 44 & $\begin{array}{l}\text { John Deere } \\
\text { 9540i WTS }\end{array}$ & 2,12 \\
\hline 45 & $\begin{array}{l}\text { John Deere } \\
\text { 9560i WTS }\end{array}$ & 2,12 & 46 & $\begin{array}{l}\text { John Deere } \\
\text { 9580i WTS }\end{array}$ & 2,12 & 47 & $\begin{array}{l}\text { John Deere } \\
\text { 9780i CTS }\end{array}$ & 2,12 & 48 & $\begin{array}{c}\text { Deutz Fahr } \\
5650 \mathrm{H} \\
\end{array}$ & 2,12 \\
\hline 49 & Deutz Fahr 5660HTC & 2,12 & 50 & $\begin{array}{c}\text { Deutz } \\
\text { Fahr6040 } \\
\end{array}$ & 2,12 & 51 & $\begin{array}{c}\text { Deutz Fahr } \\
6060 \\
\end{array}$ & 2,12 & 52 & $\begin{array}{c}\text { Deutz Fahr } \\
6060 \mathrm{HTS}\end{array}$ & 2,12 \\
\hline 53 & Deutz Fahr6065HTS & 2,12 & 54 & $\begin{array}{c}\text { ACTIVA } \\
7242 \\
\end{array}$ & 2,12 & 55 & $\begin{array}{l}\text { John Deere } \\
1450 \text { CWS }\end{array}$ & 2,13 & 56 & $\begin{array}{c}\text { John Deere } \\
\text { W } 330\end{array}$ & 2,13 \\
\hline 57 & New Holland TC5060 & 2,14 & 58 & $\begin{array}{l}\text { New Holland } \\
\text { TC } 5070\end{array}$ & 2,14 & 59 & \begin{tabular}{|l} 
New Holland \\
TC 5080
\end{tabular} & 2,14 & 60 & $\begin{array}{l}\text { New Holland } \\
\text { TC 56M }\end{array}$ & 2,14 \\
\hline 61 & $\begin{array}{l}\text { New Holland TC56M } \\
\text { RS }\end{array}$ & 2,14 & 62 & \begin{tabular}{|c|} 
New Holland \\
TC56H RS \\
\end{tabular} & 2,14 & 63 & $\begin{array}{l}\text { New Holland } \\
\text { TC 56H Plus } \\
\end{array}$ & 2,14 & 64 & $\begin{array}{l}\text { New Holland } \\
\text { CL } 6060\end{array}$ & 2,14 \\
\hline 65 & $\begin{array}{l}\text { New Holland CSX } \\
7060\end{array}$ & 2,14 & 66 & $\begin{array}{l}\text { New Holland } \\
\text { CL560 } \\
\end{array}$ & 2,14 & 67 & \begin{tabular}{|c|} 
New Holland \\
TX 63
\end{tabular} & 2,14 & 68 & $\begin{array}{l}\text { New Holland } \\
\text { TX 65Plus }\end{array}$ & 2,14 \\
\hline 69 & $\begin{array}{l}\text { New Holland } \\
\text { CS540 }\end{array}$ & 2,14 & 70 & $\begin{array}{l}\text { CASE } \\
\text { CT } 5050\end{array}$ & 2,14 & 71 & $\begin{array}{c}\text { CASE } \\
\text { CT } 5060\end{array}$ & 2,14 & 72 & $\begin{array}{c}\text { New Holland } \\
\text { AL 59 Kollina } \\
\text { Plus } \\
\end{array}$ & 2,16 \\
\hline 73 & ЛИДА 1300 & 2,17 & 74 & $\begin{array}{c}\text { New Holland } \\
\text { CS } 6050\end{array}$ & 2,17 & 75 & ЕНИСЕЙ 950 & 2,18 & 76 & \begin{tabular}{|c|} 
ЕНИСЕЙ КЗС \\
954 \\
\end{tabular} & 2,18 \\
\hline 77 & ЕНИСЕЙ 1200 & 2,18 & 78 & $\begin{array}{c}\text { ЕНИСЕЙ } \\
1200 \mathrm{M} \\
\end{array}$ & 2,18 & 79 & $\begin{array}{c}\text { ЕНИСЕЙ } \\
1200-1 \\
\end{array}$ & 2,18 & 80 & $\begin{array}{c}\text { ЕНИСЕЙ } \\
1200-1 \mathrm{M} \\
\end{array}$ & 2,18 \\
\hline 81 & ЕНИСЕЙ 1200НМ & 2,18 & 82 & $\begin{array}{c}\text { ЕНИСЕЙ } \\
1200-1 Н М\end{array}$ & 2,18 & 83 & $\begin{array}{c}\text { ЕНИСЕЙ } \\
\text { 1200РМ }\end{array}$ & 2,18 & 84 & \begin{tabular}{|c} 
Руслан на базе \\
Енисей 1200 \\
M \\
\end{tabular} & 2,18 \\
\hline 85 & Кедр-1200 & 2,18 & 86 & $\begin{array}{c}\text { Deutz Fahr } \\
5435 \mathrm{H} \\
\end{array}$ & 2,22 & 87 & $\begin{array}{c}\text { Deutz Fahr } \\
5445 \mathrm{H}\end{array}$ & 2,22 & 88 & $\begin{array}{c}\text { Deutz Fahr } \\
5465 \mathrm{H} \\
\end{array}$ & 2,22 \\
\hline 89 & Deutz Fahr 5485HT & 2,22 & 90 & $\begin{array}{c}\text { SAMPO SR } \\
2035 \mathrm{M} \\
\end{array}$ & 2,22 & 91 & $\begin{array}{l}\text { SAMPO SR } \\
2035 \\
\end{array}$ & 2,22 & 92 & $\begin{array}{l}\text { SAMPO } \\
\text { SR } 2045 \\
\end{array}$ & 2,22 \\
\hline 93 & $\begin{array}{l}\text { SAMPO SR } \\
2065\end{array}$ & 2,22 & 94 & $\begin{array}{c}\text { SAMPO SR } \\
2065 \\
\end{array}$ & 2,22 & 95 & $\begin{array}{c}\text { SAMPO SR } \\
\text { 2085TS } \\
\end{array}$ & 2,22 & 96 & ACTIVA 7244 & 2,23 \\
\hline 97 & ACTIVA 7245 & 2,23 & 98 & MF 7260 Beta & 2,23 & 99 & $\begin{array}{l}\text { FENDT } \\
5220 \mathrm{E}\end{array}$ & 2,23 & 100 & $\begin{array}{l}\text { FENDT } \\
5250 \mathrm{E}\end{array}$ & 2,23 \\
\hline 101 & $\begin{array}{l}\text { FENDT } \\
5270 \mathrm{C} \\
\end{array}$ & 2,23 & 102 & $\begin{array}{c}\text { Challenger } \\
644 \\
\end{array}$ & 2,23 & 103 & $\begin{array}{c}\text { Challenger } \\
645 \\
\end{array}$ & 2,23 & 104 & $\begin{array}{c}\text { Challenger } \\
648 \\
\end{array}$ & 2,23 \\
\hline 105 & \begin{tabular}{|l} 
Laverda \\
1950 LX \\
\end{tabular} & 2,23 & 106 & $\begin{array}{l}\text { Laverda } \\
\text { 2050LX } \\
\end{array}$ & 2,23 & 107 & $\begin{array}{l}\text { Laverda } \\
\text { 2350LX }\end{array}$ & 2,23 & 108 & $\begin{array}{c}\text { Laverda } \\
21.50 \mathrm{LXE}\end{array}$ & 2,23 \\
\hline 109 & \begin{tabular}{|l} 
Laverda \\
25.50 LXE
\end{tabular} & 2,23 & 110 & MF 36RS & 2,3 & 112 & $\begin{array}{c}\text { CLAAS } \\
\text { AVERO } 240 \\
\end{array}$ & 2,36 & 113 & $\begin{array}{c}\text { CLAAS } \\
\text { AVERO } 160 \\
\end{array}$ & 2,36 \\
\hline 114 & $\begin{array}{l}\text { CLAAS DOMINATOR } \\
150\end{array}$ & 2,36 & 115 & \begin{tabular}{|c|} 
CLAAS \\
DOMINATOR \\
140 \\
\end{tabular} & 2,36 & 116 & \begin{tabular}{|c} 
CLAAS \\
DOMINATOR \\
130 \\
\end{tabular} & 2,36 & 117 & $\begin{array}{c}\text { CLAAS } \\
\text { LEXION } 750\end{array}$ & 2,37 \\
\hline 118 & CLAAS LEXION 740 & 2,37 & 119 & \begin{tabular}{|c|} 
CLAAS \\
LEXION 630 \\
\end{tabular} & 2,37 & 120 & \begin{tabular}{|c|} 
CLAAS \\
LEXION 620 \\
\end{tabular} & 2,37 & 121 & $\begin{array}{c}\text { CLAAS } \\
\text { LEXION530 }\end{array}$ & 2,37 \\
\hline 122 & CLAAS LEXION 520 & 2,37 & 123 & $\begin{array}{c}\text { CLAAS } \\
\text { LEXION } 510 \\
\end{array}$ & 2,37 & 124 & К3С-12 & 2,5 & 125 & $\begin{array}{c}\text { John Deere T } \\
660 \\
\end{array}$ & 2,53 \\
\hline
\end{tabular}




\begin{tabular}{|c|c|c|c|c|c|c|c|c|c|c|c|}
\hline 1 & 2 & 3 & 4 & 5 & 6 & 7 & 8 & 9 & 10 & 11 & 12 \\
\hline 126 & $\begin{array}{l}\text { John Deere } \\
\text { T670 }\end{array}$ & 2,53 & 126 & $\begin{array}{c}\text { John Deere Hill master } \\
\text { 9660i WTS }\end{array}$ & 2,53 & 127 & $\begin{array}{l}\text { John Deere } \\
\text { 9640i WTS }\end{array}$ & 2,53 & 128 & $\begin{array}{l}\text { John Deere } \\
\text { 9660i WTS }\end{array}$ & 2,53 \\
\hline 129 & $\begin{array}{l}\text { John Deer } \\
9680 \text { i WTS }\end{array}$ & 2,53 & 130 & $\begin{array}{l}\text { Deutz Fahr } \\
5680 \mathrm{H}\end{array}$ & 2,53 & 131 & $\begin{array}{l}\text { Deutz Fahr } \\
5690 \mathrm{HTC}\end{array}$ & 2,53 & 132 & $\begin{array}{l}\text { Deutz Fahr } \\
6090 \mathrm{HTS}\end{array}$ & 2,53 \\
\hline 133 & $\begin{array}{l}\text { Deutz Fahr } \\
\quad 6090\end{array}$ & 2,53 & 134 & $\begin{array}{l}\text { Deutz Fahr } \\
6095 \mathrm{HTS}\end{array}$ & 2,53 & 135 & $\begin{array}{l}\text { John Deere } \\
\text { 1550WTS }\end{array}$ & 2,56 & 136 & $\begin{array}{l}\text { New Holland } \\
\text { CSX7080 }\end{array}$ & 2,57 \\
\hline 137 & $\begin{array}{c}\text { New } \\
\text { HollandTX66 }\end{array}$ & $2,57 \mid$ & 138 & $\begin{array}{l}\text { New Holland } \\
\text { TX68 }\end{array}$ & 2,57 & 139 & $\begin{array}{l}\text { New Holland } \\
\quad \text { CS640 }\end{array}$ & 2,57 & 140 & $\begin{array}{l}\text { New Holland } \\
\quad \text { CS660 }\end{array}$ & 2,57 \\
\hline 141 & CASE CT5070 & 2,57 & 142 & CASE CT5080 & 2,57 & 143 & $\begin{array}{l}\text { New Holland } \\
\text { CS6070 }\end{array}$ & 2,6 & 144 & $\begin{array}{l}\text { New Holland } \\
\text { CS6080 }\end{array}$ & 2,6 \\
\hline 145 & $\begin{array}{l}\text { New Holland } \\
\text { CS660 } \\
\text { (nicht EU) }\end{array}$ & 2,6 & 146 & SAMPO SR 3035 & 2,66 & 147 & $\begin{array}{l}\text { SAMPO SR } \\
3045 \mathrm{C}\end{array}$ & 2,66 & 148 & $\begin{array}{l}\text { SAMPO SR } \\
3065 \mathrm{~L}\end{array}$ & 2,66 \\
\hline 149 & $\begin{array}{l}\text { SAMPO SR } \\
\text { 3085L TS }\end{array}$ & 2,66 & 150 & ACTIVA7246 & 2,67 & 151 & MF7270 Beta & $2,67 \mid$ & 152 & $\begin{array}{l}\text { FENDT } \\
6250 \mathrm{E}\end{array}$ & 2,67 \\
\hline 153 & $\begin{array}{l}\text { FENDT } \\
6300 \mathrm{C}\end{array}$ & $2,67 \mid$ & 154 & $\begin{array}{l}\text { Challenger } \\
646\end{array}$ & 2,67 & 155 & $\begin{array}{l}\text { Challenger } \\
652\end{array}$ & $2,67 \mid$ & 156 & $\begin{array}{l}\text { Laverda } \\
\text { 256Rev }\end{array}$ & 2,67 \\
\hline 157 & Laverda M 305 & 2,67 & 158 & Laverda M 306 & 2,67 & 159 & $\begin{array}{c}\text { Laverda M } 306 \\
\text { LS 4WD } \\
\end{array}$ & 2,67 & 160 & $\begin{array}{l}\text { Laverda } \\
\text { 2560LX }\end{array}$ & 2,67 \\
\hline 161 & Laverda2760LX & 2,67 & 162 & Laverda28.60LXE & 2,67 & 163 & MF7274 Cerea & 2,8 & 164 & MF7278 Cerea & 2,8 \\
\hline 165 & $\begin{array}{c}\text { Amako MF } 7274 \\
\text { CEREA } \\
\end{array}$ & 2,8 & 166 & $\begin{array}{c}\text { Amako MF } 7278 \\
\text { CEREA }\end{array}$ & 2,8 & 167 & $\begin{array}{l}\text { FENDT } \\
8300 \\
\end{array}$ & 2,8 & 168 & $\begin{array}{l}\text { FENDT } \\
8350\end{array}$ & 2,8 \\
\hline 169 & Challenger654 & 2,8 & 170 & $\begin{array}{l}\text { Challenger } \\
658\end{array}$ & 2,8 & 171 & $\begin{array}{l}\text { Laverda } \\
225 \mathrm{Rev}\end{array}$ & 2,8 & 172 & $\begin{array}{l}\text { Lave } \\
255\end{array}$ & 2,8 \\
\hline 173 & Laverda M 303 & 2,8 & 174 & Laverda M 304 & 2,8 & 175 & \begin{tabular}{|} 
Laverda M 304 \\
LS 4WD
\end{tabular} & 2,8 & 176 & \begin{tabular}{|c|} 
Laverda255 AL \\
4WD
\end{tabular} & 2,8 \\
\hline 177 & $\begin{array}{c}\text { CLAAS LEXION } \\
770\end{array}$ & 2,83 & 178 & CLAAS LEXION 760 & 2,83 & 179 & $\begin{array}{c}\text { CLAAS LEXION } \\
670\end{array}$ & 2,83 & 180 & \begin{tabular}{|c|} 
CLAAS LEXION \\
660
\end{tabular} & 2,83 \\
\hline 181 & $\begin{array}{c}\text { CLAAS LEXION } \\
650 \\
\end{array}$ & 2,83 & 182 & CLAAS LEXION 640 & 2,83 & 183 & $\begin{array}{c}\text { CLAAS LEXION } \\
560 \\
\end{array}$ & 2,83 & 184 & \begin{tabular}{|c|} 
CLAAS LEXION \\
550 \\
\end{tabular} & 2,83 \\
\hline 185 & \begin{tabular}{|c|} 
CLAAS LEXION \\
540 \\
\end{tabular} & 2,83 & 186 & CLAAS LEXION 540C & 2,83 & 187 & $\begin{array}{c}\text { CLAAS LEXION } \\
450 \\
\end{array}$ & 2,83 & 188 & КЗС-14 & 2,83 \\
\hline 189 & $\begin{array}{c}\text { CLAAS LEXION } \\
560 \text { TERRA } \\
\text { TRAC }\end{array}$ & 2,83 & 190 & $\begin{array}{c}\text { CLAAS LEXION } \\
570\end{array}$ & 2,83 & 191 & $\begin{array}{c}\text { CLAAS LEXION } \\
570 \text { Montana }\end{array}$ & 2,83 & 192 & $\begin{array}{c}\text { CLAAS LEXION } \\
580\end{array}$ & 2,83 \\
\hline 193 & \begin{tabular}{|c|} 
CLAAS LEXION \\
580 TERRA \\
TRAC \\
\end{tabular} & 2,83 & 194 & $\begin{array}{l}\text { CLAAS МЕДИОН } \\
330 \mathrm{H}\end{array}$ & 2,93 & 195 & $\begin{array}{l}\text { CLAAS МЕДИ- } \\
\text { ОН } 310\end{array}$ & 2,93 & 196 & $\begin{array}{c}\text { CLAAS } \\
\text { TUCANO } \\
430 \\
\end{array}$ & 2,93 \\
\hline 197 & $\begin{array}{c}\text { CLAAS } \\
\text { TUCANO } \\
330\end{array}$ & 2,93 & 198 & $\begin{array}{l}\text { CLAAS TUCANO } \\
320\end{array}$ & 2,93 & 199 & $\begin{array}{c}\text { CLAAS MEGA } \\
350\end{array}$ & 2,93 & 200 & $\begin{array}{c}\text { CLAAS МЕДИ- } \\
\text { OH } 340\end{array}$ & 3,51 \\
\hline 201 & $\begin{array}{c}\text { CLAAS } \\
\text { TUCANO } \\
480\end{array}$ & 3,51 & 202 & $\begin{array}{l}\text { CLAAS TUCANO } \\
470\end{array}$ & 3,51 & 203 & $\begin{array}{c}\text { CLAAS } \\
\text { TUCANO } \\
450\end{array}$ & 3,51 & 204 & $\begin{array}{c}\text { CLAAS } \\
\text { TUCANO } \\
440\end{array}$ & 3,51 \\
\hline 205 & $\begin{array}{c}\text { CLAAS } \\
\text { TUCANO } \\
340\end{array}$ & 3,51 & 206 & $\begin{array}{l}\text { CLAAS MEGA } \\
370\end{array}$ & 3,51 & 207 & $\begin{array}{c}\text { CLAAS MEGA } \\
360\end{array}$ & 3,51 & & & \\
\hline
\end{tabular}

Резулътаты исследований. Полученные результаты обработаны методами математической статистики по алгоритму [8]. В итоге определено, что распределения длины и диаметра молотильного барабана, коэффициента длины молотильного барабана по диаметру имеют нормальный закон, описываются выражением (2) [4] и отли-

чаются статистиками $\bar{x}_{j}, \sigma_{x_{j}}$, которые вычис- лены и приведены в табл. 2.

$$
f^{\prime}(x)=\frac{n_{x}}{\left(\sigma_{x} \sqrt{2 \pi}\right)} \exp \left[-\frac{(x-\bar{x})^{2}}{2 \sigma_{x}^{2}}\right]
$$

Сравнение эмпирических и теоретических законов рядов распределения исследуемых и вы- 
Статистики рядов распределения длины, диаметра и коэффициента длины молотильного барабана по диаметру зерноуборочных комбайнов

\begin{tabular}{|c|c|c|c|c|c|}
\hline Показатель & $\begin{array}{c}\text { पисло } \\
\text { наблюдений } \\
n_{x} \\
\\
\end{array}$ & $\begin{array}{c}\text { Математичес- } \\
\text { кое } \\
\text { ожидание } \\
\overline{x_{j}}\end{array}$ & $\begin{array}{l}\text { Стандарт } \\
\sigma_{x_{j}}\end{array}$ & $\begin{array}{c}\text { Доверительный интер- } \\
\text { вал среднего значения } \\
\text { при уровне значимости } \\
\alpha=0,95\end{array}$ & $\begin{array}{c}\text { Коэффициент } \\
\text { вариации } \\
\text { v, \% }\end{array}$ \\
\hline$L_{\sigma}, \mathrm{M}$ & 208 & 1,396 & 0,177 & $\begin{array}{c}1,37 \ldots 1,42 \\
\text { (рис. } 1-1)\end{array}$ & 12,68 \\
\hline$D_{\sigma, \mathrm{M}}$ & 209 & 0,62 & 0,073 & $\begin{array}{c}0,61 \ldots 0,63 \\
\text { (рис. } 2-1)\end{array}$ & 11,8 \\
\hline$\psi_{L / D}$ & 207 & 2,359 & 0,429 & $\begin{array}{c}2.30 \ldots . .2 .42 \\
(\text { рис. } 3-1)\end{array}$ & 18,2 \\
\hline
\end{tabular}

численных параметров комбайнов (рис. 1-3) выполнено с помощью критерия Пирсона.

У ряда распределения длины молотильного барабана зерноуборочных комбайнов относительно малый коэффициент вариации - 12,68 \%. Для $95 \%$ рассматриваемых моделей комбайнов значения длины барабана составляют 1,0-1,7 м (см. рис. 1,2 ), длина молотильного барабана изменяется в 1,7 раза.

Ряд распределения величин диаметра барабана зерноуборочных комбайнов имеет также небольшой коэффициент вариации - 11,8 \%. С доверительной вероятностью 0,95 определено, что диаметр молотильного барабана комбайнов составляет 0,474-0,766 м (см. рис. 2,3 ); значение диаметра изменяется в 1,62 раза.

Для ряда распределения величин коэффициента длины молотильного барабана по диаметру

$\psi_{L / D}$ коэффициент вариации составляет $18,2 \%$.

У 95 \% анализируемых моделей зерноуборочных комбайнов коэффициент длины барабана по диаметру $\psi_{L / D}=1,5-3,22$ (см. рис. 2,3); он из-

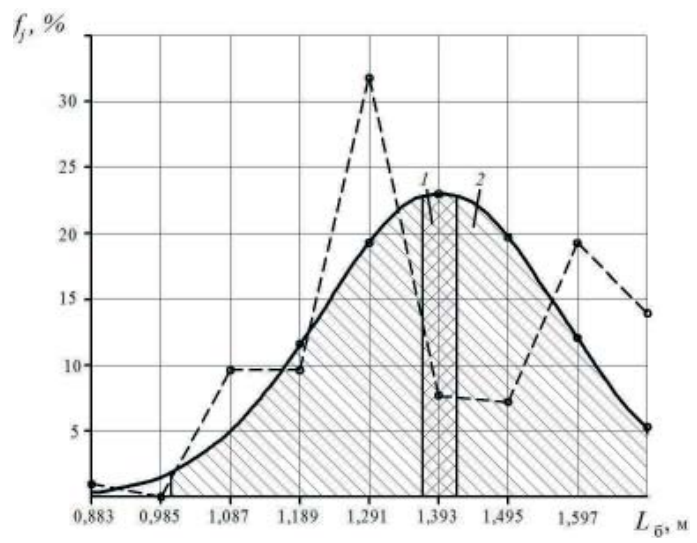

Рис. 1. Распределение длины молотильного барабана:

- - - эмпирическое; —— теоретическое меняется в 2,14 раза.

Можно предположить, что изменения исследованных показателей связаны с общим подходом проектных организаций к выбору таких параметров, как длина и диаметр молотильного барабана зерноуборочных комбайнов. Это может быть обусловлено относительно стабильными физико-механическими свойствами зерновых культур, с которыми взаимодействуют комбайны, а также предназначением зерноуборочных

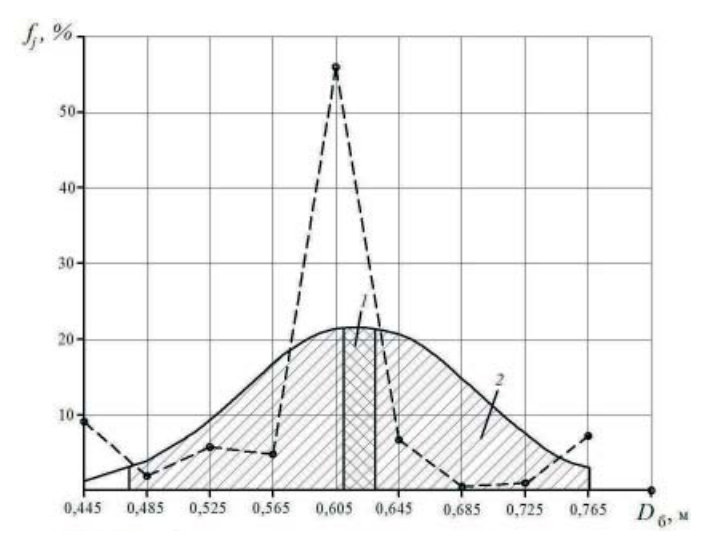

Рис. 2. Распределение диаметра молотильного барабана:

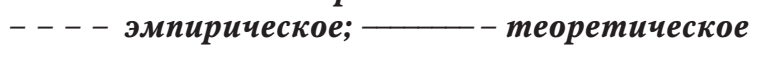

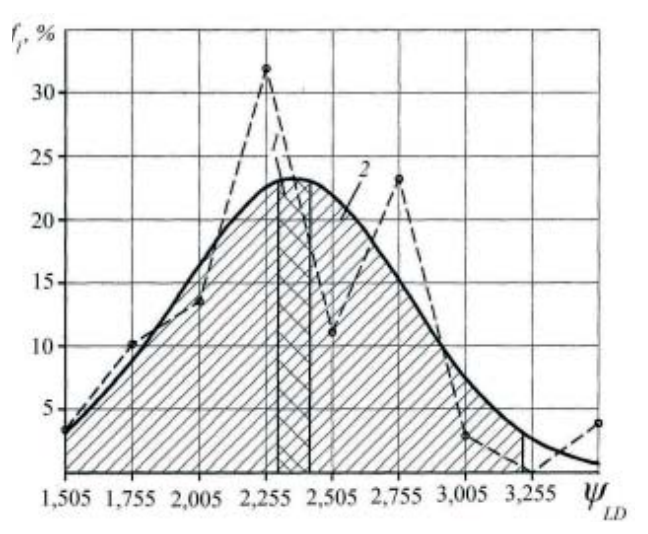

Рис. 3. Распределение коэффициента длины молотильного барабана по диаметру: - - - - эмпирическое; — - теоретическое 
комбайнов для конкретных климатических зон и условий работы.

Полученные результаты согласуются с ранее проведенными исследованиями [11] и дополняют их.

Заключение. Получены теоретические законы рядов распределения длины и диаметра молотильного барабана зерноуборочных комбайнов отечественных и зарубежных компаний - производителей сельскохозяйственной техники. Определен коэффициент длины молотильного барабана по диаметру для зерноуборочных комбайнов различных моделей и модификаций основных ведущих мировых компаний, получен теоретический закон его распределения.

\section{СПИСОК ЛИТЕРАТУРЫ}

1. Демин Е.Е., Серебряков А.А., Ананьева С.Л. Зависимости мощности двигателя, площади решет и соломотряса зерноуборочных комбайнов // Научная мысль. - 2015. - № 3. - С. 110-113.

2. Демин Е.Е., Стариев А.С., Ананьева С.Л. Зависимости площади решет, соломотряса и длины молотильного барабана зерноуборочных // Инновационные направления развития технологий и технических средств механизации сельского хозяйства: материалы Междунар. науч.-практ. конф., посвящ. 100-летию Воронежского государственного аграрного университета имени императора Петра I. - Воронеж, 2015. - С. 310-313.

3. Демин Е.Е., Стариев А.С., Серебряков А.А. Энергонасыщенность и материалоемкость зерноуборочных комбайнов // Техника будущего : перспективы развития сельскохозяйственной техники: сб. науч. тр. ФГОУ ВПО КубГАУ. - Краснодар, 2013. - С. 215-225.

4. Демин Е.Е., Стариеев А.С., Серебряков А.А. Исследование коэффициентов решет по площади соломотряса и по длине молотильного барабана зерноуборочных // Механизация и электрификация сельского хозяйства. - 2016. - № 10. - С. 22-25.

5. Дмитриенко А.И., Поздняков Ю.М. Развитие современных зерноуборочных машин // Техническое и кадровое обеспечение инновационных технологий в сельском хозяйстве: материалы Междунар. науч.- практ. конф. в 2 ч. - Минск, 2014. - Ч. 1. - С. 99-101.

6. Жалнин Э.В. О классификации зерноуборочных комбайнов // Техника будущего : перспективы развития сельскохозяйственной техники: сб. науч. тр. ФГОУ ВПО КубГАУ. - Краснодар, 2013. С. $215-225$.

7. Липкович Э.И. Процессы обмолота и сепарации в молотильных аппаратах зерноуборочных комбайнов: пособие для конструкторов зерноуборочных машин. - Зерноград, 1973. - С. 32.

8. Литтл Т.М., Хиллз Ф.Д. Сельскохозяйственное опытное дело. Планирование и анализ / пер. с англ. Б.Ф. Кирюшина; под ред. и с предисловием Д.В. Васильевой. - М.: Колос, 1981. - 320 с.

9. Стариев А.С., Иванов С.А., Серебряков А.А. Зависимости мощности двигателя, массы и объема бункера зерноуборочных комбайнов // Проблемы и перспективы инновационного развития мирового сельского хозяйства: сб. науч. тр. - Саратов, 2013. С. 282-284.

10. Стариев А.С., Серебряков А.А., Ананьев В.А. Результаты анализа площади решет и соломотряса зерноуборочных комбайнов // Научная мысль. 2015. - № 3. - С. 59-62.

11. Труфляк Е.В., Трубилин Е.И. Современные зерноуборочные комбайны. - Краснодар: КубГАУ, 2013. - 320 c.

Демин Евгений Евгеньевич, $\partial-p$ техн. наук, проф. кафедры «Техническое обеспечение АПК», Саратовский государственный аграрный университет имени Н.И. Вавилова. Россия.

Старцев Александр Сергеевич, канд. техн. наук, доиент кафедры «Техническое обеспечение АПК», Саратовский государственный аграрный университет имени Н.И. Вавилова. Россия.

Ананьев Вячеслав Андреевич, магистрант кафедры «Техническое обеспечение АПК», Саратовский государственный аграрный университет имени Н.И. Вавилова. Россия.

Мавзовин Владимир Святославович, канд. техн. наук, доцент кафедры «Математика и математическое моделирование», Саратовский государственный аграрный университет имени Н.И. Вавилова. Россия.

410056, г. Саратов, ул. Советская, 60.

Тел.: (8452) 22-84-47.

Ключевые слова: зерноуборочные комбайны; технические характеристики; длина; диаметр; молотильный барабан; законы распределения.

\section{THE RESEARCH RESULTS OF LENGTH AND DIAMETER OF THE GRINDING DRUM COMBINE HARVESTER HARVESTER}

Demin Evgeny Evgenyevich, Doctor of Technical Sciences, Professor of the chair "Technical support of AIC", Saratov State Agrarian University named after N.I. Vavilov. Russia.

Startsev Aleksander Sergeevich, Candidate of Technical Sciences, Associate Professor of the chair "Technical support of AIC”, Saratov State Agrarian University named after N.I. Vavilov. Russia.

Ananiev Vyacheslav Andreevich, Post-graduate of the chair "Technical support of AIC", Saratov State Agrarian University named after N.I. Vavilov. Russia.

Mavzovin Vladimir Svyatoslavovich, Candidate of Technical Sciences, Associate Professor of the chair "Mathematics and Mathematical Modeling", Saratov State Agrarian University named after N.I. Vavilov. Russia.
Keywords: combine harvesters; specifications; length; diameter; grinding drum; laws of distribution.

As a result of researches of sizes of technical characteristics of combine harvesters of domestic and foreign models and modifications values of length and diameter of the hammer drum of combines are analyzed. Theoretical and empirical laws of distribution series, mathematical expectation, mean square deviation, coefficient of variation, confidence interval of mean value, $95 \%$ range of length and diameter distribution of the grinding drum of combine harvesters and the length coefficient of the grinding drum in diameter are obtained. 